\title{
RELIGIOSIDAD POPULAR, TERRITORIO Y PODER; SANTUARIOS SUPRACOMUNALES Y SIMBOLIZACIÓN DE LAS RELACIONES INTRACOMARCALES
}

Juan AGUDO TORRICO *

\section{INTRODUCCIÓN. IMÁGENES Y SANTUARIOS RURALES: SOCIALIZACIÓN Y APROPIACIÓN SIMBÓLICA DEL ESPACIO}

Las unidades de observación que han servido de base para la elaboración del presente artículo, hacen referencia, de forma directa, al trabajo de campo realizado en dos lugares de Andalucía, ambos incluidos en lo que es Sierra Morena, pero pertenecientes a dos provincias distintas y a comarcas muy alejadas entre sí y con una experiencia histórica diferente. El primero de ellos sería el Santuario de la Virgen de Guía en la Comarca del Valle de los Pedroches, al norte de la provincia de Córdoba; el segundo el de la Reina de los Angeles, en la comarca septentrional onubense de la Sierra de Aracena.

Ambos comparten la condición de supracomunidad que nos permite tomarlos como objeto de análisis de nuestra reflexión. Sin embargo, manifestando el contenido dinámico que como tales referentes simbólicos tienen, su significado ha variado en el transcurso del tiempo, así como las razones que los han hecho objeto de "disputa".

El concepto de santuario lo utilizamos como el Iugar sagrado que alberga una imagen de especial devoción, que la hace objeto de visita y adoración por parte de devotos ${ }^{1}$ que no tienen porqué ser exclusivamente de la población en que se

1. En este sentido, coincidimos con la consideración de W. Christian (1976) de santuario como "lugar donde hay una imagen o reliquia que recibe una devoción particular" con una valoración en sí mismo "por Ia devoción de la gente y no por una característica histórica o artística inherente a un edificio o institución". Si bien, no deberían ser desdeñadas estas últimas características (estableciendo, por lo demás, una relación inversa que explicaría la relevancia histórica o arquitectónica precisamente por la importancia que se le ha dado), y en cuanto a las razones de la conversión de la imagen/reliquia en objeto preferente de devoción y peregrinaje, los motivos sociopolíticos o económicos que determinaron la

* Departamento de Antropología Social y Sociología. Universidad de Sevilla. 
encuentra, y sin que su origen responda al carácter institucionalizado formal que encontramos en otros lugares de culto: parroquias, humilladeros, ermitas urbanas o rurales con la advocación de santos con implicaciones protectoras estandarizadas por su funcionalidad profiláctica o protectora de plagas o animales. Puede darse la circunstancia de que algunos de estos últimos lugares de culto tengan a su vez la condición de santuarios, tal y como la estamos perfilando, bien sea por albergar además de la titular a una imagen de especial relevancia, con los atributos milagrosos que la hagan objeto de devoción preferente, o por serlo su titular de por sí; y cumplir ambas funciones, institucionalizada-formal y de condición extraordinaria por su potencialidad milagrosa.

En todo caso, la imagen custodiada en el santuario ha tenido que demostrar su condición de especial relevancia como intermediaria: en el lugar en el que se encuentra y a través de ella se ha debido producir una revelación de la divinidad, una teofanía demostrada mediante un milagro, aparición, etc. que la singularice. De este modo avalaría la razón de su existencia e importancia y, en lo que a nosotros nos interesa, actuará como factor clave en la posibilidad de conversión, al margen de su condición mariana o de cualquier otra figura representativa del santoral católico, de un icono/signo en un símbolo connotativo: acorde con el contenido polisémico de los símbolos, ha pasado a expresar, además del que emane de su valoración religiosa primaria, otros significados únicamente comprensibles dentro de un contexto cultural específico (Leach, 1985), de un código cultural más complejo que hace inteligible la información transmitida por la combinación de los signos y símbolos en juego; con una operatividad manifiesta en la recreación de identificaciones colectivas, inducción de sentimientos y emociones colectivas e individuales, etc. Las imágenes adquieren mediante este proceso de contextualización polisémica un valor en sí mismas, no sustituibles o intercambiables incluso por otros iconos que representan idénticos referentes religiosos ${ }^{2}$.

La simbiosis santuario-imagen es igualmente relevante, y no siempre ha sido objeto de análisis. Al igual que la exaltación o decadencia de una imagen tendría su reflejo inmediato en la importancia del lugar en el que se encuentra (rituales en torno al santuario, romerías o peregrinaciones), este mismo lugar puede tam-

elección del lugar es una razón que por olvidada o transformada, no deja tampoco de ser relevante, e incluso es posible que en origen fuera determinante en la exaltación de dicho culto.

2. I. Moreno Navarro (1990b) ha puesto de manifiesto en repetidas ocasiones la importancia, para la comprensión de la cultura popular andaluza, del uso que se hace de las imágenes religiosas, al transformarse su dimensión icónica en simbólica-emblemática de códigos culturales más complejos, no exclusivamente reductibles en su explicación al contenido religioso primario. 
bién actuar como factor clave en cuanto a la importancia del culto a la imagen que custodia: condición jurídica del territorio y cambios que haya tenido en relación a rectificaciones de términos municipales o procesos de desamortización que modificasen la situación jurídica del santuario-lugar, decadencia o aumento de la importancia demográfica, económica, y político-administrativa de las poblaciones que los sostienen y acuden a ellos, las propias peculiaridades naturales del paraje en que se ubique, etc., son también elementos a considerar en la capacidad de exaltación y conversión de una determinada imagen-santuario en referente devocional con determinadas implicaciones tanto religiosas como de otra índole sociocultural.

Indudablemente, el santuario o ermita, en cuanto que edificio formal destinado a albergar "a", no tendría valor en sí mismo. Es la imagen que debe custodiar, y la que "decidió" ${ }^{3}$ el lugar donde erigirlo la que le dota de significado. Pero una vez construido se ha convertido en centro simbólico-ceremonial como elemento imprescindible de los rituales en torno a su imagen titular: sitio de culto para quienes acuden al lugar durante el año, recepción y custodia de ofrendas (exvotos) que atestiguan los favores recibidos, eje de los rituales en honor de la imagen (procesiones, romerías), lugar de acogida de romeros, etc.

Todo lo cual hace que cuando hablemos en adelante de santuario, lo haremos en relación simbiótica de imagen sagrada-lugar sagrado. Pero, ¿qué razones determinaron la elección de estos lugares, su revalorización para el colectivo que los va a utilizar en el grado sumo que supone su sacralización?

Las razones últimas se nos perderían hoy en la noche de los tiempos si lo que pretendemos es afirmar motivos de una "objetividad histórica" incuestionable. Refiriéndonos de forma concreta a los santuarios rurales, a la razón que motivó su erección y conservación en condiciones de un mayor esfuerzo ${ }^{4}$, Ia

3. Nos referimos en estos casos casi en exclusiva a santuarios marianos. Los mitos de origen responden con frecuencia a unos modelos arquetipo, acorde con la importancia que las actividades agropastoriles han tenido en la economía y configuración del poblamiento en Andalucía, de aparición en un árbol o fuente; pero lo que demostraría la singularidad de su deseo de ser adorada en el lugar específico de su aparición serían los hechos milagrosos que la acompañan: imposibilidad física de ser movida del lugar, desaparición del lugar (o del zurrón o sitio en el que la transportaban) donde la depositaban para volver a aparecer en el lugar de origen, etc. Con lo cual la imagen dejaría de ser una "muñeca" encontrada sin más, para autentificar su condición de imagen sagrada y milagrosa, y, lo que es igualmente relevante, indicar donde y por quienes desea ser adorada, generando una relación de identificación recíproca que la convierte, o posibilita su conversión, en imagen-emblema de la colectividad.

4. En contraposición, y en gran medida como medio de compensar la necesidad de condensar el contenido religioso que justifique su mantenimiento, es en estos santuarios rurales donde encontraremos con mayor frecuencia las imágenes de mayor atracción popular y/o institucional de buena parte de las poblaciones andaluzas. Son los que albergan las imágenes patronales o consideradas de especial significación en la protección de personas, animales y coschas; a la vez que dan lugar a las numerosas romerías 
sacralización de parajes con unas especiales condiciones naturales (oquedades, peñas, cimas de cerros, fuentes) sería una de ellas. Con lo que la presencia de imágenes-santuarios cristianos no vendría a ser en muchos casos sino la continuación de unos usos precristianos (J. Caro Baroja, 1974; J. Prat i Carós, 1989; J.M. Díez Taboada, 1989); cuando no el medio de dotar de un nuevo contenido doctrinal a espacios "paganos" (incluso sacralizando la existencia de ruinas no necesariamente vinculadas a santuarios de especial relevancia), con la consecuencia indirecta de perpetuar su condición sagrada.

En su continuidad y función social, las razones interpretativas de su presencia son igualmente múltiples. Su finalidad religiosa vendría dada por su condición votiva, bien en agradecimiento por la intercesión específica en algún hecho o circunstancia extraordinaria, o simplemente por el reconocimiento estandarizado de su especificidad protectora ante tal o cual enfermedad o plaga. Sin embargo, en tanto que la imagen es adoptada como símbolo emblemático de un determinado grupo social, pasa a constituir su símbolo identitario: la pertenencia a un determinado oficio, a una localidad, e incluso a una comarca o subcomarca, se mostrará y redefinirá cíclicamente mediante los rituales en torno a la imagen correspondiente, visualizándose a sí mismos y con relación a otros grupos humanos por medio de dichos rituales desarrollados en el lugar específico delimitado por el santuario.

Los santuarios se transformarían en sitios neutrales, lugares donde recrear "espacios y tiempos culturales de igualitarismo y permisividad social" (I. Moreno, 1990a) que enfatizan la idea de pertenencia a un colectivo simbólicamente integrado ${ }^{5}$, en contraposición a los conflictos internos que puedan existir dentro

que los convierten en los lugares "neutrales" idóneos donde reproducir y renovar, cada año, el sentimiento, o al menos la pretensión, de comunidad simbólica integradora; en contraste con la desigualdad socioeconómica real observable en la vida cotidiana y reproducida en la propia configuración del espacio social del núcleo urbano.

5. A lo largo de todo el artículo utilizaremos el término "comunidad", con todos los cuestionamientos hechos al mismo y nunca como sinónimo de organización social homogénea, integrada y carente de conflictos, como uno de los referentes identitarios, en términos ideológicos, utilizados po el individuo. La pertenencia a un lugar y colectivo con el que se comparte una experiencia cultural, intemalizada, se puede poner de manifiesto en la instrumentalización de determmadas expresiones y símbolos culturales (tradiciones, paisajes, historia, etc.) utilizados como referentes globalizadores.

La doble polaridad semántica atribuida a los símbolos rituales (Tumer, 1980) cobraría una relevancia significativa cuando nos referimos a un símbolo "comunal", aceptado, dado su contenido polísémico, por todos o una mayoría de la colectividad. En este sentido, el contenido ideológico, manipulable, del símbolo en cuanto que referido al orden social que pretende testimoniar, legitimar y reproducir, contrastaría con el polo sensorial a partir del cual el símbolo de referencia cobra un contenido identitario, aglutinador, estimulando deseos y emociones que son compartidos por todos en lo que sería la "ilusión de comunidad". El "entorno-mundo" así recreado (H. Velasco, 1991) se expresaría en forma de "comunidad 
de las mismas demarcaciones sociales de referencia (grupal, comunal supracomunal).

Pero también podemos encontrar otras explicaciones, igualmente prosaicas que nos remiten a la apropiación de un territorio mediante la construción (identi. ficación con) y mantenimiento de un determinado santuario ${ }^{6}$. Las ennitas rura. les, e incluso las periurbanas, se habrían construido ${ }^{7}$ en verdaderos espacios liminales en una doble acepción simbólica y real. En términos simbólicos, estas ermitas han servido para integrar los espacios rurales en el contexto "civilizador' de la población de origen; actuarían de "centralizadoras" (incluso en otros tiempos en términos fácticos al actuar a modo de "templos" cotidianos para los habitantes dispersos en sus alrededores) de estos espacios rurales, haciendo presente a la propia colectividad tanto por medio de la imagen relevante que cobija como un bien común, como, sobre todo, con el desplazamiento y presencia cíclica (romería) de los propios habitantes e instituciones locales (clero, munici» palidad) en el lugar. Los santuarios se convierten durante un tiempo cultural en espacio de acogida y reproucción del propio contexto global de la comunidad: los romeros alteran la relación de oposición medio rural-medio urbano para introducir el principio de complementariedad que debe regir entre ambos.

Con lo cual, las ermitas actuarían como catalizadoras entre los dos espacios, transformando el espacio rural en un espacio humanizado; modificando así la liminalidad (frontera) simbólica referida.

El concepto de "territorio", de espacio humanizado, lo entendemos en su acepción ecológico-cultural. Su concepción geográfica, con límites más o menos "lógicos", no nos interesa tanto como su percepción de espacios socioculturales que actúan como factor clave en la gestación de procesos identitarios de quienes los habitan y utilizan; procesos que los dotan de una "personalidad" que hace que

simbólica" capaz de activarse en momentos rituales (o, por ejemplo, en situaciones conflictivas en las que exista un sentimiento de agravio o perjuicio para el conjunto de la colectividad), y en tomo a determinados símbolos culturales como puedan ser las imágenes patronales que las representen.

6. En mi trabajo (1991) he analizado algunos ejemplos de ermitas conservadas como testimonio de antiguos poblados desaparecidos, de manera que su persistencia e incluso las romerías cíclicas, testimoniaban el derecho de los "herederos" de aquellos lugares, desplazados a las nuevas poblaciones.

7. Sin embargo, en el presente, eI nuevo auge por la construcción (o revitalización de su importancia) de emitas rurales tiene una finalidad muy diferente. La condición votiva, centralidad de hábitat disperso, demarcación de territorios limítrofes, etc., ha sido desplazada por un contenido en el que resalta la idea de la "romería" como fin en sí misma: aunando la justificación explícita de la devoción a una determinada imagen al factor lúdico sobresaliente que conlleva el desarollo de la misma. Si bien, no dejan de aparecer, evidenciados en un esquema más o menos elaborado, los factores socioculturales a los que hemos aludido: ocasión propiciatoria para la manifestación de la identidad de grupos sociales, reproducción de la estructura social local, etc. 
la defensa del "derecho" al mismo se convierta en una razón colectiva al margen incluso de los intereses particulares ${ }^{8}$. Hablamos, por lo tanto, de espacio social en un sentido amplio, en lo que es la delimitación de un espacio físico de referencia (territorio) y en lo que supone de manifestación de la identidad/reproducción del grupo humano que lo controla: se es alajareño, hinojoseño, etc. En la medida que se pertenece a un pueblo en el doble significado de haber nacido en un lugar concreto e identificarse, por haberla compartido, con la experiencia cultural del colectivo que lo habita.

Su existencia se define, en consecuencia, sobre la base de esta persoalidad diferenciadora, articulada sobre un sistema de relaciones sociopolíticas y económicas, que tendrán, como no, su vertiente en manifestaciones de identificación/ diferenciación y reproducción simbólica de los colectivos que los habitan. El territorio puede convertirse en uno más de los marcadores culturales que se procuren resaltar como propios por su mayor singularidad. Y en este sentido, los santuarios e imágenes van a ser con frecuencia elementos culturales claves en los procesos de cristalización y reproducción de identidades locales ${ }^{9}$ y supralocales, propiciando rituales y ceremonias a través de los cuales se expresen.

De este modo, el recurso a la conformación simbólica del espacio, a su territorialización, puede servimos para configuara la percepción más adecuada a la realidad sociocultural de los habitantes de un espacio físico, por encima o de forma complementaria a los criterios organizativos que establecen "unidades" territoriales en base a pretendidas "homogeneidades" geográficas, o factores históricos que justifiquen determinadas demarcaciones político-administrativas, judiciales o eclesiásticas. Aunque estos últimos pueden ser también factores no desdeñables en la conformación de sentimientos de identidad tales como los comarcales (J. Caro Baroja, 1968), donde la racionalidad en el aprovechamiento

8. En términos relativos, dado que el control de un determinado territorio y la potencialidad económica del mismo revertirá necesariamente en las condiciones de vida del colectivo global.

9. Con un matiz importante. La sociedad local no puede considerarse un factor determinante, estructural, de la identidad individual o colectiva. Unicamente representa un importante marco territorial, matizado con los rasgos culturales específicos de su vivencia histórica, del sistema de identidades que definen en cada individuo y colectivo social su identidad a partir de tres principios estructurantes: etnia, género, y clase y actividad profesional (I. Moreno, 1991). En consecuencia, al hablar de identidad local lo haremos del discurso identificador que, a partir de dichos sistema de identidades, mixtifica ideológicamente la realidad social. Con bastante frecuencia los marcadores culturales instrumentalizados para la autopercepción como colectivo global diferenciado serán extraídos en su devenir histórico no de forma neutral o por generación espontánea, sino como resultado de los diferentes discursos identitarios elaborados acorde con el entramado ideológico más favorable a los grupos sociales dominantes. Otra cosa es que el mantenimiento y reproducción continuada de los mismos conserve históricamente la misma relación entre referente y significado. 
de unos recursos ecológicos similares puede ser matizada por las peculiaridades orográficas que favorezcan una percepción unitaria del espacio, la pertenencia a unidades históricas de larga tradición, etc. Si bien, como es el caso de una de las macrounidades de observación elegidas, la Comarca de Aracena, su inclusión en la unidad geográfica de Sierra Morena no presupone su autopercepción como unidad "comarcal-cultural"; por el contrario, la compleja subcomarcalización de su territorio queda de manifiesto en la red de santuarios, vinculaciones supracomarcales, etc.

En este contexto teórico, las ermitas han actuado igualmente como demarcadores de unos límites reales. La idea de sacralidad nos remite al carácter sancionador, máximo, con el que se pretende reforzar determinados valores socioculturales, aplicables no sólo al ámbito de las creencias, de las relaciones con lo sobrenatural, sino también a aspectos más pragmáticos de la organización sociopolítica de los seres humanos y, por supuesto, las relaciones del hombre con su medio natural. El recurso a la sacralización del territorio, al refuerzo simbólico en el contacto con "otro" territorio, en los límites o fronteras (F. Delpech, 1990), ha constituido una práctica histórica habitual en otros tiempos ${ }^{10}$ en los que esta forma de sancionar los límites que demarcaban el espacio propio, se instituían, una vez aceptada la concordia, en un valor jurídico a respetar.

El medio natural territorializado se convierte en un espacio imprescindible, soporte de lo que serán las actividades económicas básicas para la subsistencia de los habitantes del lugar; pero también un espacio cuyo control ${ }^{11}$ ha sido con frecuencia causa de conflicto con otros colectivos. Nos referimos a los que han sido y son relaciones de poder entre poblaciones que compartieron y comparten un mismo territorio. En los dos casos que analizamos, su condición de centros religiosos supracomunales nos permite observar, a través de la "pugna" por controlarlos o ejercer determinados derechos, las relaciones mantenidas entre las poblaciones que convergen en ellos.

10. En referencia, claro está, a un tiempo en el que el derecho consuetudinario avalado por la tradición actuaría entre los diversos modos de afirmar "derechos jurídicos" sobre espacios rurales, prerrogativas jurídicas o fiscales, etc. Principios consuetudinarios que en muchos casos serían fundamentales en la plasmación de la delimitación de términos municipales, consecución de la autonomía municipal, etc., en el transcurso de los siglos.

La posesión y derechos de propiedad sobre una ermita se encontraría dentro de estos principios recurrentes que testimoniarían un aval tradicional, justificando, como veremos, un derecho preeminente sobre el territorio en el que se encuentra.

11. En el amplio sentido de la palabra: de ser posible incluyéndolo en la consideración de término municipal; pero también, en cuanto a lo que supone de control administrativo, centralidad de servicios, pugna por la "importancia" y reconocimiento como tal de una u otra población ("capital", comarcal, subcomarcal, etc.). 
No en balde, y aunque desconozco si este fue el motivo de la tradición de que no haya una sola ocasión festivo-ceremonial en la que confluyan todas las poblaciones que han reglamentado rigurosamente durante siglos el uso de la ermita e imagen de la V. de Guía, la tensión ocasionada por lo que venimos diciendo de la desigual distribución de los recursos económicos y humanos, hizo que se llegara a prohibir la presencia de los habitantes de las diferentes poblaciones en un mismo día y santuario supracomunal ${ }^{12}$; aunque, en lo que sería un ejemplo más de la ambivalencia con la que puede ser instrumentalizados unos mismos referentes culturales, también hemos citado el uso que se puede hacer de ellos como espacios neutrales, de "permisibilidad social", lo que haría de estos mismos encuentros momentos de concordia, de reproducción tácita de la posición ocupada por cada colectividad en relación al territorio y demás recursos compartidos; cuando no de un tiempo para la ritualización del conflicto que merme su expresión en términos de la realidad cotidiana (C. Lisón, 1980).

\section{NIVELES DE SIGNIFICACIÓN DE LOS SANTUARIOS E IMÁGENES SUPRACOMUNALES}

En consecuencia, las manifestaciones festivo-ceremoniales que se originan en torno a los mismos nos interesan en cuanto expresan simbólicamente, en rituales que precisan los derechos de cada población, el mantenimiento y reproducción de los sistemas socioeconómicos que articulan la coexistencia intercomunal sobre espacios definidos. Su análisis pormenorizado (J. Escalera, 1990; J. Agudo y J. Escalera, 1989) debe hacerse en un doble nivel: en principio, en un niveI intracomunal, el mismo hecho de que la imagen, al singularizarse dentro del sistema devocional local, se transforma en un marcador cultural clave en la conformación y reproducción ideacional de la identidad local, la convierte, junto al santuario que la cobija, en un capital simbólico de interés relevante en la reproducción del sentimiento de pertenencia a una comunidad imaginaria; en la recreación de la "ilusión de comunidad" (l. Moreno, 1991) que conforma Ia población de la que sea "patrona". Por lo tanto, el análisis de la estructura social de cada localidad nos pondrá de manifiesto la diferenciación (l. Moreno, 1974) entre lo que es la "hermandad identificación" comunal/supracomunal, y lo que

12. William Christian (1991: 147-149) cita la existencia de sendos decretos del obispado de Burgos (1575) y de Toledo (1583) prohibiendo la concentración de diferentes pueblos en un mismo santuario y día, para evitar los conflictos que inevitablemente ello provocaba, motivados por asuntos de lindes, animales, tierras comunales, etc. 
serían sus "hermandades organización" controladas por los grupos sociales que detentan el poder político y social: el sostenimiento del culto a la imagen se convertiría para estos grupos sociales, en un sentido contrapuesto a su instrumentalización real como signo de prestigio, en la "obligación" simbólica de resarcir a la comunidad de los beneficios obtenidos de la misma; comprometiéndose de forma destacada en la conservación-exaltación del bien comunal que representa la imagen. E incluso con el acto de la redistribución simbólica de parte de los beneficios obtenidos al asumir la "obligación" de costear, o participar generosamente, los gastos que originen el mantenimiento de su culto y los rituales festivo-ceremoniales que origine.

Pero esta misma participación destacada no será sino uno de los medios de hacer patente su preeminencia en la jerarquización social; de ahí que sea igualmente relevante observar quienes son en cada momento los que detentan el control del capital simbólico representado por imagen y santuario para analizar e] proceso de sustitución de unas "elites" por otras (también de la preeminencia de derechos de unas poblaciones sobre otras), indicativo del relevo de las viejas élites tradicionales, generalmente vinculadas al control del medio de producción básico que ha supuesto la tierra, por otros grupos sociales emergentes, de una procedencia dispar pero que verán así reconocida la posición de privilegio alcanzada. (J. Escalera, 1990; J. Agudo, 1990).

El segundo nivel al que hiciéramos referencia lo constituirá la relación intercomunal generada en torno a la imagen. En ocasiones (Reina de Los Angeles en Alájar), la formalización de esta supracomunalidad en hermandades organizadas reflejó el propio entramado de alianzas entre las diferentes oligarquías locales. Pero, en la medida en que a través de quienes participan constituyendo la hermandad y con independencia del número de romeros, rituales concretos, etc., lo hacen las poblaciones de origen, esta misma relación lo va a ser entre un pueblo y otro: es Aracena, Linares, etc., quien acude al santuario, o, en contraposición, no se acudirá o tendrá interés en asistir al santuario en las fechas más relevantes para "no hacerle la fiesta a" un determinado pueblo, lo mismo que los enfrentamientos (ritualizados a través de canciones e incluso en ocasiones materializado en situaciones de agresión física o momentos de tensión) serán entre "los de" un determinado pueblo y otro, sin que se individualice con nombres concretos o se planteen como ofensas personales, sino colectivas. En los dos casos que analizamos nos vamos a encontrar con relativa frecuencia este proceso metonímico que proyecta las relaciones concretas de quienes participan organizadamente (hermandades institucionalizadas), o han tenido que ver con acontecimientos específicos, de uno y otro carácter, en un plano globalizador de la comunidad de referencia en sí. Como ejemplo significativo, las "Concordias" o 
acuerdos para establecer el tiempo de rotación de la Virgen de Guía han sido firmadas entre los "pueblos" que comparten la imagen y el santuario: el derecho a la imagen o la pérdida del mismo, tanto en las referencias escritas como en las "creencias" y afirmaciones orales de uso cotidiano, lo es de uno u otro "pueblo"; el incumplimiento de su hermandad organización supondría la pérdida o menoscabo del derecho común. No es extraño, sin embargo, que entre los pueblos que la comparten desconozcan entre sí cuáles son los rituales que sigue cada uno de ellos, los modelos organizativos de sus hermandades, etc. Del mismo modo, continuando con la referencia específica a la V. de Guía, el análisis de los rituales seguidos en cada una de estas poblaciones es extraordinariamente significativo en cuanto, según cada caso, la imagen, referente idéntico para todos ellos, se convierta de colectiva en comunal (patrona identificadora de una sola colectividad) o simplemente permanece como grupal, símbolo identitario mientras duren los rituales de un sector concreto de la población; pero en todos los casos, haya sido o no adoptada como la principal devoción identitaria, el conjunto de la colectividad se hará presente como testamentaria del "derecho" del pueblo en contraposición a los "otros". En el desarrollo de los rituales de cada hermandad habrá un tiempo marcado en el que cumplen con la obligación de representar al colectivo global, ejercitan la obligación que han asumido de hacer valer los derechos del mismo sobre imagen y santuario, y otro en el que se limitan a expresarse como el segmento social que por propio deseo han conformado, haciendo patente su diferenciación intracomunal en rituales específicos (comensalismo, vestimentas, etc.) que les muestra como "hermandad" grupal observada por el resto del colectivo.

En ambas devociones, las relaciones intercomunales que han generado en ningún caso han sido planteadas en un esquema de igualitarismo que pudiera presuponer, en su transposición simbólica, equiparable, un acceso por igual a los recursos existentes. Por el contrario, con el aval de una historia reinterpretada de mil maneras en beneficio de una determinada posición o como reivindicación de agravios pasados y/o presentes, hablamos de unas relaciones de poder basadas en la desigualdad. Frente a las teorías que verían en estos rituales la simbolización de las relciones de concordia entre poblaciones convecinas, hay que interpretarlas desde una perspectiva conflictivista: siempre que sea posible se procurará poner de manifiesto aquello que les diferencia, los derechos y preeminencias de unos sobre otros; sólo que la ritualización del conflicto, a la vez que pone de manifiesto su existencia, atenua las consecuencias al limitarlo a un tiempo y espacio ritualizado en lugar de ser abierto y permanente.

Ante la necesidad de compartir unos recursos naturales limitados, la preeminencia de una población sobre otra se mide en un orden jerárquico que garantiza (más en el pasado que en el presente) para el concejo beneficiado un acceso 
privilegiado a los mismos (extensión y calidad del territorio controlado), que se manifestará en términos demográficos, prestigio político, etc., y, en consecuencia, en la acaparación de los resortes político-administrativos que las transformarán en "cabeceras" de dichos territorios.

En un sentido complementario, la posición o control sobre una imagen y santuario de fuerte atracción supracomunal, cuando la población que lo controla se sitúa en una relación de inferioridad en el esquema sociopolítico referido, el uso que se haga de su derecho a administrar el santuario y controlar la imagen, supone la consecución de un igualitarismo (e incluso supremacía) simbólica que contrasta con su realidad en el organigrama territorial del área.

Así pues, santuarios e imágenes son instrumentalizados como un "capital simbólico" (P. Bourdieu, 1980) en el sentido dado a este concepto en cuanto referido a una realidad "simbólica", "religiosa", aparentemente inútil, en términos del pragmatismo teóricamente aplicable a nuestras relaciones sociales y actos cotidianos; pero que, en la medida que está inserto en el entramado de un sistema simbólico, con la sobrestima de su sacralidad, actúa como referente estructurante de dicha realidad. Y por lo tanto, como tal capital simbólico, su posesión o control supone una renta de prestigio manipulable en beneficio de determinados grupos sociales y/o de las propias comunidades en sí. No es lo importante el acudir a estos lugares para celebrar determinadas ceremonias, sino el "como" y "quienes" acuden, los "derechos" esgrimidos sobre los mismos, el "fundamento" en el que se argumentan dichos derechos, el "sentimiento" de propiedad o de "derecho a" al margen de las disposiciones jurídicas (civiles o eclesiásticas); con lo que si en sí no tiene por que ser necesariamente una fuente de poder, la instrumentalización que se haga de santuario-imágenes si pone de manifiesto la diversidad de situaciones en las relaciones de poder intercomunales, al tiempo que el posicionamiento (de defensa o rechazo) de las mismas.

La instrumentalización del símbolo ritual, en este caso el icono religioso con los consiguientes rituales que genera, actuaría como un fuerte condensador de ideas (Turner, 1980) donde el contenido sensorial, emotivo, no debe sin embargo hacernos olvidar, en lo que es su utilización (capital simbólico) por quienes detentan el poder político-social, la manipulación de este factor, capaz de generar la imagen de comunidad, en su propio beneficio; haciendo patente el otro polo semántico atribuido por Turner a todo símbolo ritual: el ideológico o normativo que actúa en beneficio del orden social existente. La misma ilusión de comunidad intralocal podemos extrapolarla al ordenamiento de las relaciones intercomunales, basadas en la supuesta homogeneidad que daría su inclusión en un marco geográfico comarcal común, el aprovechamiento de unos recursos similares, una historia semejante, etc., pero, de igual modo, el análisis de los 
"acuerdos" para compartir un mismo símbolo pondrá de manifiesto el deseo de su manipulación en beneficio de un determinado grupo social o población: las ocasiones en que se relacionen serán el momento ritual (romerías, confluencia en el santuario, etc.) de procurar patentizar la posición ocupada por cada uno de estos grupos sociales.

En defiitiva, el código de relaciones que subyace en este lenguaje simbólico pone de manifiesto, más a través de "sentimientos" ${ }^{13}$ que de manera formalizada ${ }^{14}$, lo que son las situaciones de "normalidad" y/o "conflicto" perceptibles en las relaciones intercomunales.

Su inclusión dentro de un sistema simbólico religioso, con su consiguiente estructura y capacidad estructurante (P. Bourdieu, 1971), da origen a una lectura inversa del significado y función de los santuarios-imágenes compartidos. Lo que se dilucida es la posesión de un "bien social", en su contenido de imagen sagrada intercesora del bienestar colectivo, pero también como icono convertido en símbolo identitario de la comunidad y, por lo tanto, al margen ahora de la propia significación religiosa, instrumentalizable en los procesos de autoidentificación contrastiva con otros colectivos ${ }^{15}$. Sólo que es a su vez una imagen invocada y deseada formalmente por estos otros colectivos, situados en una posición objetiva desigual en términos jurídicos, pero que no obstante la consideran un "bien social" de forma similar a la comunidad propietaria, incluso en ocasiones con la condición de patronal.

13. Podríamos decir que latentes y retroalimentados en términos de un tiempo cultural cotidiano que fundamenta buena parte de la identidad del nosotros en la diferenciación con el ellos más próximo y por lo tanto perceptible, con la consiguiente generación de mitificaciones diferenciadoras que nos hacen "más trabajadores", menos usurpadores de terrenos (proyectando una ideología identitaria colectiva sobre un territorio común), etc. Estos sentimientos, y por lo tanto recreaciones basadas en elaboraciones subjetivas, pueden llegar a tener una incidencia real en las actitudes y comportamientos colectivos, respaldados en una idea de "comunidad" y regulados incluso ritualmente.

14. Lo que no quiere decir que no se trate de formalizar en cuanto sea posible, ya sea con un reconocimiento jurídico pleno, como sería la pugna centenaria del derecho de Villanueva del Duque al santuario de la Virgen de Guía, o al menos consensuado y respetado entre las poblaciones que confluyen en el interés por un mismo bien social: reconocimiento de derechos o privilegios para ocupar determinados espacios en los templos o alrededores de las ermitas, en las procesiones, o tiempos de "llegadas" al santuario: formalización de hermandades que manifiesten, al margen del número de inscritos o participantes en los actos ceremoniales, la presencia de la población de origen, etc.

15. Distinguiendo siempre lo que son advocaciones que por su reconocida posición dominante en la escala de intercesión con lo sobrenatural, son objeto de cultos masivos pero individualizados (por ejemplo los santuarios de Fátima, Guadalupe, etc.), de los modelos de culto supracomunal que analizamos. En el primer caso no existiría conflicto, por el contrario, la presencia del santuario supone únicamente una repercusión favorable para la comunidad que la custodia. 
El mito de origen ${ }^{16}$ (lugar, propiedad del territorio donde se ubica, personaje que la encuentra) es para las demás poblaciones un principio cuestionable en cuanto al control de la imagen, si bien este último derecho de control es indefectiblemente incuestionable en términos absolutos para la comunidad "propietaria" jurídicamente; acaparadora de una renta de prestigio que pretenderá hacer valer.

\section{SANTUARIO DE LA VIRGEN DE GUÍA. CONTINUIDAD HISTÓRICA FORMAL Y TRANSFORMACIÓN DE SIGNIFICADOS}

El análisis de las relaciones mantenidas en torno al mismo, por su interés, hay que remitirlo a un proceso diacrónico que refleja con notable nitidez la evolución de las relaciones de poder entre las poblaciones que lo han compartido (alianzas, ejercicio de derechos jurisdiccionales enfrentados a derechos tradicionales, etc.). Nivel de análisis interrelacionable con otro no menos destacable: la importancia que ha tenido el santuario e imagen dentro del sistema devocional de cada localidad, acorde con la consideración dada a la imagen de patronal o meramente grupal, posición que ocupe en la escala jerárquica devocional, no necesariamente inmutable, etc. De hecho, mientras que para Alcaracejos y Villanueva del Duque se ha mantenido y consolidado como la imagen de mayor relevancia, para Hinojosa del Duque y Dos Torres ha quedado relegada a una devoción secundaria, incluso con problemas para el sostenimiento y reproducción de sus hermandades y rituales.

El santuario de la V. de Guía se encuentra en las afueras de la localidad de Villanueva del Duque. El templo, de destacadas dimensiones y calidad arquitec-

16. El valor que se le da a esta circunstancia no debe desdeñarse. En el caso de la Virgen de Guía en Los Peroches, siendo el referente el mismo, hay al menos tres mitos de origen básicos completamente diferentes. En todos los casos lo que se pretende es "demostrar" el derecho del pueblo que lo narra a la imagen. Aunque también encontramos en Dos Torres un mito de extraordinario sincretismo que pretende dar respuesta al por que del derecho compartido de "todas" las poblaciones: la imagen, aparecida en una encina, fue hallada por un vecino de Alcaracejos, en una finca propiedad de un hinojoseño pero que estaba enclavada en el término municipal de Villanueva del Duque. Torremilano adquirió sus derechos por haber sido el pueblo que más ayudó en la construcción de la ermita, levantada en el lugar del hallazgo. La quinta población, Fuente la Lancha, no nos aparece como protagonista de ninguno de estos mitos, dada su condición de pequeña aldea dependiente de Hinojosa del Duque hasta el siglo pasado.

La otra gran tradición sería la de los tres guerreros oriundos de Hinojosa del Duque, Alcaracejos y Torremilano (Dos Torres) que antes de separarse, y en agradecimiento por la protección que les dispensó la Virgen de Guía durante la guerra, acuerdan erigir un santuario en la encrucijada de los caminos que llevaban a las tres poblaciones y a donde acudirían en los años venideros; el derecho de Villanueva del Duque provendría de ser la pohlación más próxima al lugar donde se separaron, con lo que quedó la ermita bajo su custodia. 
tónica, data de la segunda mitad del s. XV, desconociéndose su origen, posibles razones de su erección en un lugar despoblado, etc.

Escasez de información que también encontramos en cuanto al origen de las poblaciones que lo han compartido. En todo caso son poblaciones posteriores a la ocupación castellana, s. XIII, del territorio del Valle de Los Pedroches, asentadas sobre un espacio "vacío" y marginal respecto al centro jurídico-administrativo (ciudad de Córdoba) al que se asigna la comarca en los primeros tiempos de la ocupación castellana. El resultado debió ser un sistema de aprovechamiento en el que por la limitada presión demográfica y escasa entidad originaria de sus núcleos poblacionales, predominarán los terrenos baldíos y de aprovechamiento mancomunal.

La progresiva consolidación (s. XIV-XV) de estos núcleos poblacionales cambiará la situación. La pugna entre poblaciones lo es a su vez por un territorio que garantice la subsistencia de sus habitantes pero también por el afianzamiento de una jerarquía de poder en función del desigual acceso al control políticoadministrativo del área, con el hecho de que incluso los centros matrices más antiguos serán desplazados por poblaciones más tardías, que elegirán como factor determinante de su asiento la mejor calidad de los suelos y no razones defensivas. La "acotación" del espacio natural en territorios "propiedad" de una u otra comunidad conllevaría un complejo corolario de pleitos, acuerdos y concordias. Y en este sentido, en la fijación de unos derechos consuetudinarios que darían pie a los jurisdiccionales, es donde jugaron un papel destacado algunas de las ermitas rurales de la comarca de Los Pedroches: concebidos como espacios sagrados/ neutrales, serán el lugar de reunión para dilucidar asuntos intercomunales (ermita de Sto. Domingo para las poblaciones del Condado de Belacázar, ermita de Piedrasantas para las Siete Viellas de realengo), pero también serán instrumentalizadas como hitos demarcadores de territorios.

Tres de los cuatro santuarios comarcales que han sido o fueron supracomunales están levantados sobre espacios periféricos, liminales, alejados de los centros poblacionales y en su tiempo objeto de aprovechamiento mancomunados. En su conjunto, las ermitas de la V. de Gracia, V. de Las Cruces y V. de Luna, conforman un rosario de santuarios sobre un territorio que podemos considerar "marginal", situado entre las poblaciones y las cadenas montañosas que circundan la penillanuera del Valle de Los Pedroches. Su supracomunidad, la confluencia sobre un mismo lugar sagrado de poblaciones que comparten (compartieron) también el territorio sobre el que se asientan, refuerza la condición de verdaderos mojones simbólicos que podemos atribuir a estos santuarios. Al igual que en el caso de los santuarios locales, sólo que ahora reflejan una propiedad colectiva, los derechos sobre el bien sagrado de la imagen y el testimonio peren- 
ne de su presencia en la ermita son la demostración del derecho al lugar, los momentos de la romería representan la traslación simbólica de la comunidad al territorio de la ermita, pero la misma presencia de la imagen, en cuanto bien protector específico (aunque excepcionalmente también lo pueda ser a la vez de otra localidad) demuestra el derecho y presencia simbólica continuada de la comunidad en y sobre el lugar: las ermitas/imágenes actúan como un fuerte aglutinante simbólico, convertidas en puntos de referencia de clara percepción.

El cuarto santuario supracomunal, el de la V. de Guía, está ubicado en un espacio central de la comarca, entre varias poblaciones, por lo que la interpretación anterior sería cuestionable. Sin embargo, varias razones validarían su inclusión dentro de esta hipótesis. En principio fue construido en un espacio que pese a su centralidad geográfica era, hasta el desarrollo tardío de la localidad de Villanueva del Duque y las demás poblaciones circundantes, un territorio muy alejado de los centros poblacionales matrices (Belalcázar, Pedroche); por lo que cabe pensar en una condición similar de territorio vacío, e incluso mancomunado, si nos atenemos a una tradición oral no confirmada con documentación escrita. Aunque es la conversión del espacio que ocupa en territorio "fronterizo" lo que va a revalorizar su posición: la creación del condado de Belalcázar en 1445 sitúa el lugar que hoy ocupa Villanueva del Duque en el límite jurisdiccional con las Siete Villas de Los Pedroches.

Pero habría otro factor histórico que refuerze su valor. Los límites orientales del condado de Belalcázar lo eran también de la jurisdicción de la villa que adquiera una mayor importancia en la subcomarca occidental en el transcurso de los siglos XIV y XV: Hinojosa del Duque. Belalcázar e Hinojosa eran las únicas entidades municipales del condado hasta que Villanueva del Duque, aldea de Hinojosa, consiga segregarse en 1631 con la oposición enconada de Hinojosa que únicamente le cede como término poco más del espacio que incluía los edificios del casco urbano; la propia ermita, distante $1 \mathrm{~km}$. quedó fuera del mismo. El consiguiente conflicto de intereses, que durará varios siglos, dará origen a numerosos pleitos con Hinojosa del Duque, mostrándonos la pugna de esta pequeña población por conseguir el territorio y derechos de acceso a los espacios mancomunados que garantizasen su supervivencia y desarrollo.

La consiguiente situación de enfrentamiento contraviene en principio varias cuestiones que podrían haber incidido en un sentido contrario: la amplitud del territorio y pertenencia a una misma entidad jurídico-administrativa debieran haber supueto una relación de concordia. Sin embargo, la existencia de tal conflicto nos refleja, siempre con referencia al acceso al bien limitado que representa el territorio y a la articulación desigual de las relaciones intercomunales en cuanto al control político-administrativo sobre el mismo, por una parte la necesidad 
de analizar la verticalidad existente en las relaciones de poder (dominio/dependencia) entre las poblaciones que lo comparten, a la vez que cuestiona la idea de la existencia de "comunidades" en su pretendida conformación y desarrollo al margen del contexto territorial e intercomunal en el que estarían ubicadas.

La pugna por la imagen/ermita revistió entre estas dos poblaciones una especial virulencia, mostrándonos en su trasposición simbólica la realidad de un enfrentamiento por cuestiones más pragmáticas, "vitales": para Hinojosa, el derecho jurisdiccional, legal, a la imagen/ermita "rural" de la Virgen de Guía es irrenunciable como un bien sagrado/territorial que ponía de manifiesto su posición dominante; para Villanueva del Duque existiría un derecho de facto por la inclusión de la ermita entre sus santuarios cotidianos, prácticamente "urbano", pero igualmente significaba un reconocimiento al pleno uso, jurisdiccional, del espacio que ocupaba.

Al menos desde el s. XVII tenemos confirmación de la condición de imagen itinerante que ha mantenido hasta hoy la V. de Guía, desplazada desde el santuario a cada uno de los cinco pueblos que la comparten: tres del condado de Belalcázar, Hinojosa del Duque, Fuente la Lancha (aldea de Hinojosa hasta 1820) y Villanueva del Duque, y dos de las Siete Villas, Alcaracejos y Torremilano (hoy integrada en la localidad de Dos Torres). En su conjunto son poblaciones muy desiguales en cuanto a potencialidad demográfica, posición en la organización territorial de la comarca, amplitud y riqueza de los territorios que ocupan, etc., sobresaliendo Hinojosa del Duque como la localidad más favorecida a lo largo de todo el proceso histórico, con una población actual de algo más de 8.000 habitantes (ha llegado a superar los 15.000), mientras que en el polo opuesto estaría Fuente la Lancha, que no alcanza los 500 habitantes, y, en una escala intermedia, las otras tres localidades con poblaciones en torno a los 2.000 habitantes. Todas ellas se caracterizan por una fuerte ruralización económica, lo que hace, dentro de las limitaciones económicas compartidas, más sobresaliente la diferencia en cuanto a recursos disponibles en favor de Hinojosa del Duque si unimos al hecho de ser el término municipal más extenso de la comarca (527 $\mathrm{km}^{2}$ ) el de mayor calidad agropecuaria. Las demás poblaciones cuentan con 137 $\mathrm{km}^{2}$ por parte de Villanueva del Duque, $179 \mathrm{~km}^{2}$ Alcaracejos, $128 \mathrm{~km}^{2}$ Dos Torres, y $7 \mathrm{~km}^{2}$ Fuente la Lancha. Desigualdad en cuanto a recursos que quedará reflejada en el acceso al bien sagrado de la propia imagen.

El desplazamiento anual cíclico a las diferentes poblaciones, que también encontraremos en la otra gran devoción subcomarcal de la Virgen de Luna (compartida entre Pozoblanco y Villanueva de Córdoba) sigulariza el modelo de devociones supracomunales de la comarca. Son numerosas las imágenes supracomunales que encontramos dispersas por todo el territorio andaluz, pero, a diferencia de los modelos de la comarca de Los Pedroches, la condición sedentaria 
de la imagen define su "territorio de gracia" a partir del santuario en el que se ubica lugar de peregrinación al que han de acudir quienes quieran hacerla su valedora; col lo que se refuerza notablemente el rol simbólico de la población propietaria de santuario/imagen (patronal y por lo tanto comunal únicamente para dicha localidad) generando con respecto a las demás poblaciones/hermandades que acudan al santua rio la relación jerárquica hermandad matriz-hermandades filiales. Sin embargo, en e caso de las Vírgenes de Guía y de Luna, su condición itinerante hace que el territori a proteger se determine de modo fragmentario a partir de sí misma, adoptando po santuario a cada templo parroquial en el tiempo en el que permanece en él; con k cual no existe la referida relación jerárquica comunidad/hermandad propietaria-co munidades/hermandades filiales.

La imagen puede ser, en consecuencia, una devoción comunal/patronal par: varias poblaciones: lo es la V. de Luna para Pozoblanco y Villanueva de Córdo ba, y la V. de Guía para Villanueva del Duque y Alcaracejos. Paralelamente, e edificio del santuario, con un valor relativo en su función de espacio sagrado reafirmaría no obstante su supracomunalidad en cuanto que lugar de acogid: durante los tiempos de espera del ciclo anual en los que la imagen, "comunal' para varias poblaciones, debe permanecer en el mismo. Por lo tanto, su conserva. ción, con los consiguientes derechos que en reciprocidad conlleva dicha obliga. ción, atañe a todas las poblaciones que acuden a él: históricamente los costes de mantenimiento del santuario de la V. de Guía se han hecho a cargo de las arcas municipales de las poblaciones "propietarias"; lo mismo que las concordias que regulan su utilización y el tiempo de permanencia de la imagen en cada pueblc están firmadas, además de por los hermanos mayores de las diferentes hermanda. des y los párrocos de cada población, también por los respectivos alcaldes; testimonio de una valoración cívico-religiosa de la imagen de notable significación.

En la medida en que la imagen es desplazada a los pueblos, los rituales y festejos más relevantes no tienen lugar en la ermita ${ }^{17}$ sino en los espacios urba-

17. Hoy es así en todas las poblaciones pero en el pasado hubo una excepción de notable sigificación. La hermandad de Hinojosa del Duque empleaba casi dos días en llegar a la ermita (distante $18 \mathrm{~km}$.) donde permanecía todo un día entero, incluida la celebración de una verbena, antes de retornas con la imagen al pueblo. Este hecho y el que se celebrara en la explanada de la ermita (distante de Villanueva del Duque $1 \mathrm{~km}$.) la feria hinojoseña de S. Blas, hay que ponerlo en relación con lo que era lá demostración no sólo del dominio jurídico sobre la ermita/territorio sino también de su "poder", discutidc por Villanueva que plantearía a través del continuo enfrentamiento por la ermita la negación sirnbólicé del mismo. Cuando se produzca en el s. XIX la separación de los términos municipales con lo que la ermita pasa definitivamente a la jurisdicción de Villanueva del Duque, la presencia de Hinojosa de: Duque en la ermita perderá huena parte de su significado, lo que explica, por un lado la paulatine disminución del tiempo de estancia en la ermita hasta que en 1959 deja de hacerse noche en ella y, de otro, el progresivo declinar de la devoción a la V. de Guía con la potenciación alternativa del culto a le imagen no compartida de la V. de la Antigua, designada "patrona" en 1957. 
nos y en los recorridos por los "caminos" 18 que conducen desde cada pueblo directamente hasta el santuario. Con lo que nos encontramos con otra lectura de la idea de neutralidad simbólica aplicable al recinto sagrado del santuario, a su conversión en lugar idóneo para la recreación de un tiempo y espacio cultural de contacto y manifestación de las diferencias intercomunales. El santuario tiene un valor neutral estricto: es el lugar de recogida y entrega de la imagen, con un tiempo regulado y vigilado de forma precisa. No existe ningún tiempo ritual en el que confluyan en él todas o algunas de las comunidades. Incluso cuando una población entrega ${ }^{19}$ la imagen y otra la recoge en el mismo día hay un tiempo de espera, neutro, en el que la imagen permanece "sola" en el santuario.

La reglamentación del uso de la imagen va a procurar atenerse al principio de evitar las posibles situaciones de tensión que con toda seguridad se hubieran originado de encontrarse en un mismo tiempo y lugar poblaciones que han tenido conflictos históricos por diversas razones, derivadas fundamentalmente de los derechos sobre espacios comunales y delimitación de términos jurisdiccionales. Aunque no siempre lograrían evitarlo, y de hecho, desde el momento que existe una estricta regulación, formalmente establecida, la no presencia física de representantes de una u otra población no significa que pueda incumplirse lo acordado. Por el contrario, esta no presencia formal conlleva un riguroso control del cumplimiento de los horarios y días acordados; cuando no se materializa sin más en la presencia física celadora en el santuario en las horas precisas, sobre todo por parte de los habitantes de Villanueva del Duque, en espera de la falta de cumplimiento de alguna de las poblaciones; lo que supondría la "pérdida" del derecho a la imagen y consecuentemente la permanencia de un mayor tiempo en su ermita, considerada como santuario local por Villanueva.

En otros casos, son determinadas "costumbres" las que trasladan la relación de vigilancia/tensión fuera del ámbito de la ermita: cánticos en las romerías por los que, con idénticas letras, se excluye (según los devotos de la localidad que la

18. Cada hermandad acude por un camino propio, considerado privativo de la misma por lo que no necesitan pedir permiso para cruzar por los diferentes términos municipales. Los rituales de las hermandades van precisamente a recalcar el recorrido por estos caminos, reseñando los momentos de transición entre el espacio urbano y rural y el cruce de un término municipal propio a otro ajeno (Alcaracejos).

19. Con la excepción, desde 1962, de Hinojosa del Duque que entrega la imagen a Villanueva deI Duque a la entrada del pueblo al devolverla el 14 de agosto, en lo que es una verdadera paradoja histórica al haber cedido un derecho propio para exaltar la fiesta mayor (la feria da comienzo con la entrega de la imagen) de la población con la que más enconadamente rivalizaron hasta el s. XIX. De hecho, reflejando hasta que punto la devoción a una imagen en sí es un valor dependiente de otros valores sociales de refuerzo, no queda memoria colectiva de los enfrentamientos (incluso físicos) del pasado, cuando lo que se dilucidaba, en torno a la excusa simbólica de una imagen sagrada era la manifestación de la prepotencia de Hinojosa sobre el espíritu combativo de supervivencia de Villanueva del Duque. 
cante) a una u otra población del derecho a la imagen y, sobre todo, la consistencia de las principales promesas o mandas no en ir andando al santuario, sino en acudir a los respectivos pueblos en los que se encuentre la imagen cuando ésta tenga que ser devuelta al santuario para ser, seguidamente, trasladada al suyo propio. De este modo los hinojoseños acudirán a Villanueva del Duque en el día establecido, los devotos de Villanueva a Hinojosa cuando sea el traslado hasta la ermita, etc,; es lo que denominan "ir a por la imagen" o "recogerla", dando testimonio de la reafirmación y derecho del pueblo de turno en el momento crucial del cambio de tenencia de la imagen.

Las cuatro Concordias o acuerdos para el reparto del uso de la imagen, fechadas en $1654,1882,1955^{20}$ y 1983 , regulan de forma precisa los días e incluso las horas a las que cada población debe acudir a recoger y entregar la imagen. Desde la concordia de 1882 quedaba recogido por escrito la obligatoriedad inexcusable de hacerlo en el tiempo y hora determinado so pena de perder el derecho a la imagen; sin embargo nos consta que al menos Hinojosa del Duque lo incumpliría en una ocasión sin que la protesta y la tensión generada sirviera para retirarle este derecho. La posición de fuerza de esta población se haría valer, al igual que, en consonancia con la desigual situación de poder que ocuparía cada población, el derecho reconocido a todas ellas a la ermita e imagen no significa una relación de igualdad. La mejor muestra de ellos lo podemos observar en la cuantificación del tiempo asignado a cada pueblo para trasladar la imagen a su parroquia:

\section{Tiempo tradicional}

- Alcaracejos: del 24 de febrero al Domingo de Resurrección.

20. Los cambios introducidos en la Concordia de 1955 son explicables a la vez que por la pérdida de la significación del origen de los viejos conflictos, por el tiempo "político" en que tienen lugar. El poder que para entonces tenía la iglesia institucional representada por el clero y la manipulación ideológica del "año mariano" entendido como de concordia universal, hicieron posible la concesión del derecho a llevarse la imagen a Dos Torres y Fuente la Lancha. Unicamente habrá una cierta resistencia "popular" por parte de Villanueva del Duque, que llegaron incluso a "esconder" la imagen para que no se la pudiera Ilevar Fuente la Lancha; sin embargo, los nuevos cambios contaron con el beneplácito de Hinojosa del Duque y Alcaracejos que no verán mermar en nada sus derechos tradicionales, mientras que Villanueva consideraba la merma del tiempo en la ermita como una pérdida del tiempo complementario que ello supone para esta comunidad "propietaria" del santuario.

La Concordia de 1983 entre otras pequeñas modificaciones (aumento del tiempo de Dos Torres en una semana y cambio de las horas solares por las que se regían los momentos de entrega y devolución de la imagen por el horario normal establecido en cada estación) introduce una modificación fundamental: que nigún pueblo pierđa el derecho a la imagen si no puede acudir en el día y hora establecido por causa justificada. Ni que decir tiene que esta claúsula no es aceptada a nivel popular y se sigue velando celosamente el cumplimiento de las fechas y horas acordadas para, en su caso, "quitarle" el derecho a la población que la incumpla. 
- Villanueva del Duque: Domingo de Resurrección al Domingo de Quasimodo y desde el 14 de agosto al primer domingo de octubre.

- Hinojosa del Duque: sábado anterior al primer domingo de mayo al 14 de agosto.

Añadido a partir de 1955

- Fuente la Lancha: desde el segundo al cuarto domingo de octubre.

- Dos Torres: del primer domingo de noviembre al primer domingo de diciembre.

Aún hoy, pese a las variaciones que podemos encontrar de un año para otro al adoptarse como referencia algunas fechas movibles del calendario litúrgico, Hinojosa del Duque la tiene alrededor de 100 días, le sigue Villanueva del Duque, entre 50 y 60 días, Alcaracejos, de 40 a 60 , Dos Torres con 30 días y Fuente la Lancha con 14. La graduación refleja un orden de importancia favorable a Hinojosa del Duque pese a que la imagen es actualmente una devoción secundaria en esta localidad y no solo no ha quedado fuera de toda pugna por ejercer cualquier derecho preeminente sobre la imagen y santuario, sino que ha cedido algunos de sus prerrogativas. El contenido religioso de una imagen es uno más entre los valores socioculturales atribuibles a un icono religioso, y en el caso que analizamos, como en otros muchos, cuando únicamente sea éste el que subsista mermará sustancialmente la propia capacidad de atracción de la imagen: desaparecida la pugna entre poblaciones con la definitiva delimitación de términos, distribuidas de forma inequívoca las funciones y grado de poder que cada pueblo detenta sobre el territorio a compartir, e inmersos todos ellos en una grave crisis socioeconómica por la creciente desestructuración de sus bases económicas agropecuarias tradicionales, no hay motivos para genera relaciones conflictivas cuando la misma imagen compartida recibe una valoración desigual en cada población, salvo entre Alcaracejos y Villanueva del Duque. Aún así, la potencialidad de generar nuevos conflicto estará siempre latnte, propia de toda relación nosotros-ellos en los que ejercer una identidad contrastiva, sólo que las razones de origen hoy han perdido toda funcionalidad.

En relación a Villanueva del Duque, el tiempo que se le asigna mantiene una relativa igualdad con el de Alcaracejos, localidades que la veneran como imagen patronal y entre las que se reproduce la mayor rivalidad por su "apropiación" simbólica. Sin embargo, cuando era Hinojosa del Duque la población que pretendía supeditar e incluso restringir los derechos de las demás poblaciones, Villanueva del Duque y Alcaracejos mantuvieron una relación de alianza (invitaciones mutuas a los respectivos festejos, etc.) que perduró, hoy olvidada, durante varios siglos. 
En el caso de Dos Torres (Torremilano) su vinculación a la devoción a la V. de Guía muestra una serie de peculiaridades cuyo detalle quedaría al margen del presente artículo. Muy probablemente a lo largo de la historia mantuvo la tradición de acudir a rendirle culto a una de las dos imágenes ${ }^{21}$ existentes, sin entrar en el cíclo de rotación de las demás poblaciones, en un único día y en su santuario, desplazándola al pueblo sólo en circunstancias excepcionales. Sin embargo, una tradición oral, con toda probabilidad "falsa" en cuanto a su fundamento histórico pero aceptada como cierta y ejemplarizadora en toda la comarca, afirmaba que el "pueblo" de Dos Torres había perdido eI derecho a la imagen por no haber acudido a por ella en su día al habérsele impedido una riada: sean cuales sean las condiciones meteorológicas o motivos de otro índole ningún pueblo debe de dejar de cumplir con el día y la hora establecida. Por lo tanto Dos Torres perdió el derecho a la imagen pero no al santuario, manteniendo su hermandad sus rituales específicos en torno a una imagen "propia" conservada en el santuario supracomunal. Cuando en 1956 le sean "devueltos" sus derechos a la imagen compartida, el conflicto surge al rechazar el tiempo "marginal" en cuanto a número de días y fechas del año que en su opinión les conceden, alegando en contra unos hipotéticos principios de igualdad con las otras poblaciones que históricamente nunca han existido. En realidad encubría el conflicto creado en la hermandad, que como institución formalizada debía hacerse cargo de la imagen, al tener que modificar sus propios rituales en lo que consideraban perder su capacidad de decisión e incluso su propia identidad grupal. El resultado fue que la hermandad retiró "su" imagen de la ermita para continuar celebrándole culto en otra ermita de la localidad, mientras "el pueblo" ( $\sin$ hermandad) se ha hecho cargo de traer y llevar la imagen supracomunal. Actualmente existen en Dos Torres dos imágenes con idéntica advocación y referencia histórica en su origen,

21. La imagen que hoy se venera, en origen una pequeña talla de $25 \mathrm{cms}$. datada en el s. XIV, no era el único icono de la ermita. Por el contrario, con una tradición que aún hoy podemos encontrar en las ermitas de la V. de Luna (Pozoblanco), V. de las Cruces (El Guijo) y V. de las Veredas (Torrecampo), existían dos iconos de la misma advocación y sin ninguna semejanza iconográfica. Una imagen, pequeña, es la conocida como "la aparecida", y Ia otra, de dimensiones normales, era la que se procesionaba. Generalmente la imagen grande ha terminado por desplazar a la pequeña, entre otras razones por su mayor idoneidad para recibir los signos de ostentación (joyas, vestidos) con los que son agasajadas por sus devotos.

En el caso de la V. de Guía también fue así. Muy probablemente fue una imagen grande, si nos atenemos a los inventarios conservados, la que recibira en el pasado un culto preferente. Con posterioridad, en un proceso confuso, la imagen pequeña acaparó todo el interés, mientras que la imagen grande pasaría a ser considerada propiedad de una sola hermandad (Dos Torres), de modo que al surgir el conflicto entre esta hermandad y los restantes "pueblos" retirarían la imagen de la ermita, con las consecuencias que referiremos. 
pero en realidad distintas en todo, desde su representación iconográfica a la capacidad de atracción devocional. Ambas tienen, en parte por esta misma "confusión" devocional, una escasa relevancia en el sistema devocional de Dos Torres ${ }^{22}$.

Por último, Fuente la Lancha reflejará en los mismos rituales respecto a la imagen supracomunal la posición socioeconómica subordinada que ha tenido en la escala de poder intercomunal. Los rituales en torno a la imagen se caracterizan por su "dependencia" respecto a los de Hinojosa del Duque. Localiza geográficamente en el camino entre Hinojosa del Duque y la ermita/Villanueva del Duque, los rituales y tiempo en el que su antigua hermandad se "apropia" de la imagen corresponden al tiempo en que Hinojosa acude a por la Virgen de Guía o la devuelve: a la entrada del pueblo es "entregada" a los lanchegos para que les rindan culto en su templo parroquial y, posteriormente, es llevada hasta el extremo opuesto de la población donde es "devuelta" a los hinojoseños para que continúen su camino hasta Hinojosa del Duque o, en sentido inverso, hasta la ermita. Hasta la concordia de 1956 no se le asigna un tiempo propio (14 días), con el correspondiente ritual de acudir directamente a la ermita para traerse y devolver la imagen. Sin embargo, de forma parecida a lo que ocurriera en Dos Torres, la vieja hermandad ha optado por mantenerse vinculada a los rituales en torno a los que se autoidentifiquen como grupo social a la vez que cumple con un derecho comunal; por el contrario, en el tiempo exclusivo que han recibido (teniendo en cuenta que la imagen podríamos considerarla como devoción patro-

22. Hay un hecho a destacar tanto en el caso de Dos Torres como de Hinojosa del Duque, y que no son tampoco únicos en la comarca. La pérdida de importancia de estos cultos supracomunales ha ido pareja al mismo desinterés de unas poblaciones para con otras, inmersas todas ellas en una crisis económica y demográfica que las ha hecho perder, en el caso de las cinco poblaciones de referencia, cerca del $50 \%$ de su població en los últimos treinta años. Al mismo tiempo, la decadencia del mundo agrario tradicional, la generalización del concepto de tiempo y valores urbanos/industriales ha significado la extición de muchos usos temporales (por ej. la medición del tiempo de los contratos, regulación de los períodos de descanso, ferias y mercados, etc., realizado en consonancia con el santoral católico), de creencias religiosas vinculadas a santos protectores de plagas y animales, etc. El resultado es un proceso de sincretismo que ha concentrado los denominados "valores tradicionales" de este mundo rural, expresado en el propio tiempo de fiestas, adaptado a la regulación del ciclo trabajo-ocio semanal/anual impuesto por la sociedad industrial como medio de garantizar la presencia tanto de quienes no realizan actividades agropecuarias como de quienes han tenido que emigrar o realizar su trabajo fuera de la comunidad. $Y$ en este marco de referencias, si bien no es extraño que hayan existido no una sino varias imágenes/ devociones patronales en cada comunidad, se ha producido el fenómeno de potenciación de determinadas devociones comunales, únicas, que concentren, en un tiempo corto y preciso, la idea de colectividad. Proceso, claramente manifiesto en estas dos poblaciones, en el que se ha buscado imágenes locales, indiscutidas en cuanto a su condición de pertenencia, antigüedad, historia, etc. 
nal no formalizada) es el "pueblo" el que se hace cargo de ejercer su nuevo derecho, con la circunstancia añadida de que son ahora las mujeres, excluidas de los momentos de mayor ritualización del tiempo tradicional, las que desempeñan el rol ritual más relevante.

\section{SANTUARIO DE LA REINA DE LOS ÁNGELES. FORMALIZACIÓN SIMBÓLICA DE LAS RELACIONES DE PODER INTERCOMUNALES}

El culto a la Reina de los Angeles reviste un interés destacado por su capacidad de aglutinar, en una proyección piramidal, tanto lo que sería un territorio o espacio social supracomunal abarcable al entorno ecológico e histórico sobre el que constituye un punto nuclear; como por su capacidad de definir niveles de integración social progresivamente más amplios, manifiestos en las formas organizativas y en la percepción del santuario como espacio físico de confluencia, en un tiempo concreto, de las colectividades que lo comparten diferenciadamente.

En este caso la imagen/santuario si podemos considerarlo de ámbito comarcal, contribuyendo a ello las propias características del lugar en el que se encuentra. Las peculiaridades de la Peña sobre la que se levanta, ubicada en un punto geográfico estratégico en los caminos que cruzan la comarca, unido a sus condiciones físicas que la convierten en una verdadera atalaya dentro de un paisaje agreste pero con una explanada que permite la concentración de numerosas personas, además de la existencia de fuentes y oquedades por su naturaleza caliza, han hecho del lugar en sí desde tiempo remotos un espacio idóneo, un lugar "fuerte", propiciatorio para el contacto con poderes sobrenaturales.

En consecuencia convergen en él varias de las razones primarias que condicionan la elección de los puntos de contato entre el hombre y la divinidad. Circunstancias que no encontramos en el santuario de la V. de Guía, determinado en su elección por factores humanos, históricos, sin relevancia por sus peculiaridades físicas.

El santuario e imagen de la Reina de los Angeles se enmarca en la idea arquetipo de supracomunidad devocional, reforzada por los factores arriba mencionados. El territorio de gracia se define a partir del lugar ocupado por el santuario/imagen, propiedad incuestionada de una sola comunidad, de la que será imagen patronal y consecuentemente identificadora de tal colectivo. Incluso con unos rituales específicos, día del "poleo" (8 de septiembre), previos a la gran romería supracomunal (9 de septiembre), en los que únicamente participan los habitantes de Alájar. 
Aunque no nos podamos detener en analizar el valor simbólico atribuible al espacio comunal de la ermita, si es importante destacar que como tal espacio sagrado que acoge un "bien comunal" constituye una realidad diferenciable incluso de otros espacios comunales, y en este sentido es obligado hacer referencia a la pugna ayuntamiento-hermandad ${ }^{23}$ por el control del lugar de la ermita. Según una tradición, la Peña fue declarada no enajenable en las desamortizaciones del s. XIX, con la consideración de bienes comunales tutelados por el concejo. Sin embargo, habría que analizar, referido a un bien que se considera por encima de su rentabilidad o aprovechamiento económico de uso y valor "comunal" en términos simbólicos, los mecanismos, no siempre con un contenido jurídico, por los que se han diferenciado y delimitado las funciones y prerrogativas de los ayuntamientos como instituciones sobre los mismos. La imagen del ayuntamiento/institución como valedor incuestionable de los derechos de la colectividad ha quedado en entredicho por la experiencia histórica, cuando intereses personales de quienes han detentado el poder local han esquilmado estos mismos bienes comunales. Por ello, hasta nuestros días existe un derecho ("propiedad") compartido del espacio de la ermita, pero el ayuntamiento queda excluido de su gestión. Durante los actos rituales desarrollados en el santuario, pese a que el pueblo se encuentra a los pies de la peña, y dada la importancia simbólica de los actos (validación/reconocimiento de la autoridad a través de la participación en la gestión y mantenimiento del bien comunal de la imagen), en estos días se nombra un "alcalce la peña" (concejal o el propio alcalde) que actúe con idénticas prerrogativas que el propio alcalde, representando a la corporación en los actos celebrados en la "casa del concejo" existente junto a la ermita, colindante con la del mayordomo; y en la que se dará a los asistentes el refresco costeado por el ayuntamiento en el día del "poleo".

De esta forma testimonia su derecho sobre el lugar, representando a una colectividad civil gestionada de forma partidista, pero sin mediatizar la labor y derechos de la "hermandad", institución socio-ceremonial que representa a la comunidad simbólica. El enfrentamiento entre ambas instituciones estará siempre

23. Hablamos de hermandad como institución que vela por el cuidado de ermita e imagen, administrando sus bienes y organizando los rituales y ceremonias en honor de su titular. Sin embargo, aunque su existencia nos aparece referenciada desde muy antiguo, eran los mayordomos, individuos que asumían por un año la obligación de costear los gastos del día en honor a la imagen, los que desempeñaban el rol más destacado hasta fecha reciente en que han sido sustituidos por la hermandad (J. Agudo, 1990) como institución de gestión colegiada y sin obligaciones económicas individualizables. Las razones son varias: creciente complejidad en la administración de los cuantiosos bienes de la imagen, elevado coste de los gastos del convite y ceremonias en honor de la imagen, desaparición de la antigua élite local o disminución drástica de las rentas provenientes de las actividades agropecuarias. 
latente hasta adquirir un protagoismo relevante cuando ambas instituciones estén personificadas por individuos pertenecientes a grupos de poder divergentes; como lo fueran en el pasado la pertenencia a clanes familiares rivales.

Pero al margen de esta manifestación de los conflictos inherentes a la propia sociedad local (las mayordomías primero y hoy el control de la hermandad organización) testimonial de forma precisa la relación cambiante en las relaciones de poder entre las personas y sectores sociales que la conforman, y al contrario que en el santuario de la V. de Guía, donde nos aparece como una constante histórica la presencia formalizada (hermandades/"pueblos") de las poblaciones que la han compartido, la supracomunidad devocional de la Reina de los Angeles presenta una condición de "informalidad" manifiesta hasta los años veinte de nuestro siglo. No existiría una presencia de "pueblos", de hermandades organizadas en los actos festivo-ceremoniales en su honor; por el contrario, la relación con la imagen revestía un carácter individual, condicionado a los festejos y rituales que celebrara la comunidad propietaria o al cumplimiento de promesas y visitas desarrolladas a lo largo del año.

Lo que no quiere decir que el lugar del santuario y el control de la imagen hayan sido siempre realidades incuestionables vinculadas a la población de Alájar. La aparición milagrosa de la imagen (mito localista alajareño) reconvierte en un código cultural católico el valor simbólico de la Peña, y por lo tanto la transforma en un capital simbólico de interés para los grupos de poder (sectores sociales e instituciones eclesiásticas o civiles) que coexisten sobre el espacio que abarca su territorio de gracia.

Al igual que en el caso de la V. de Guía, hablamos de un espacio con unos condicionantes ecológico culturales ${ }^{24}$ en el se han establecido accesos diferenciados a los recursos existentes, y por lo tanto de desigualdad en las relaciones de poder intercomunales que ello genera. $\mathrm{Y}$ en este contexto, la localidad de Aracena nos aparece como centralizadora, incuestionable hasta nuestros días, del control sobre la comarca centro oriental de la Sierra Morena onubense, con una potencialidad demográfica, extensión y calidad de su término municipal, localización privilegiada en los caminos de acceso de la Baja Andalucía hacia la sierra,

24. Aunque debamos referimos a una aparente homogeneidad, Ia comarca "natural" de la sierra norte onubense presenta una fragmentación interna que responde a una lógica ecológico-cultural que no respeta las unidades político-administrativas establecidas de forma convencional. El santuario de la Peña aúna directamente lo que sería una de estas subdivisiones, integrando incluso a comunidades a su vez cabeceras de reductos espaciales más concretos, por ejemplo Galaroza y Aracena. Si bien, ningún otro centro ceremonial posee una capacidad de atracción análoga dentro del contexto de la comarca serrana del norte de Huelva. 
etc., que la han convertido en la "capital" de la sierra. Incluso llegó a ejercer, hasta las sucesivas segregaciones municipales en el transcurso del s. XVIII, potestad jurisdiccional sobre un considerable número de poblaciones consideradas aldeas de Aracena.

Y entre estas aldeas estuvo, hasta 1700, la propia población de Alájar, por lo que su santuario "pertenecía" a Aracena. De hecho, su inserción entre los centros devocionales relevantes nos lo demuestran los testimonios documentales que tenemos acerca de la realización de rogativas y procesiones desde Aracena a Alájar, distante una decena de kms. Sin embargo, las relaciones entre Aracena y Alájar no fueron precisamente cordiales, por el contrario la documentación histórica refleja frecuentes situaciones de conflicto (M. Moreno Alonso, 1979) hasta que Alájar, lo que nos recuerda la función análoga ejercida por el santuario de la V. de Guía, quedó como territorio "fronterizo", primero al integrarse Alájar y Galaroza (1559) en el señorío del duque de Alcalá aunque continuó dependiendo administrativamente de Aracena, y posteriormente (1640) al incluirse el conjunto de Aracena y sus aldeas en los estados del conde Duque de Olivares. En ambos casos se situó en la confluencia de los territorios de Aracena con las tierras de realengo de Almonaster la Real. Condición estratégica que queda reflejada en el hecho de ser la peña prácticamente el punto de confluencia de los términos municipales de Fuenteheridos, El Castaño, Linares y Alájar, establecidos con la definitiva fragmentación del territorio de Aracena a comienzos del s. XIX.

A pesar de todo ello, de la atracción devocional ejercida por la imagen, no surgirían hermandades filiales hasta fechas relativamente recientes; aunque si resulta incuestionable la considerable extensión (más en el pasado que en el presente) que ha llegado a abarcar su "territorio de gracia", rebasando el ámbito comarcal para hacerse presente en localidades como Valverde del Camino, Zalamea, e incluso en localidades del sur de Extremadura: Fuentes de León, Fregenal, Higuera la Real, etc. Importancia (capital simbólico) devocional que reafirma el interés por el control de la "Patrona de la Sierra".

Tendremos que esperar para el surgimiento de dichas hermandades a otro momento histórico. La desaparición del régimen feudal unido a los procesos de desamortización, así como al auge de otras actividades muy lucrativas relacionadas con el contrabando y la producción de corcho, generó desde fiales del s. XIX una burguesía comarcal que se hará con los resortes del poder local. La consolidación de su posición socioeconómica privilegiada sobre la base del control de la tierra y de la producción agropecuaria, culmina con el desarrollo de una ideología conservadora que va a recurrir a la reabsorción de viejos símbolos religiosos sobre los que ejercer ahora un patronazgo que les justifique. Sin olvidar que son las manifestaciones festivo-ceremoniales vinculadas a los mismos, momentos 
culturales idóneos para poner de manifiesto su grado de poder, en la ostentación de sus donativos, clientela que concentren, etc.

En este contexto, la fecha de 1924 en la que tiene lugar la primera romería "comarcal" es considerada de especial significado (J. Escalera Reyes, 1991) por las circunstancias que concurren en ella. Tiene lugar en un período en el que la especial conflictividad sociopolítica es respondida con un fortalecimiento generalizado de los instrumentos ideológicos representados por las manifestaciones festivo-ceremoiales, de profunda imbricación en la cultura popular andaluza. Al mismo tiempo, quien lo promueve, el marqués de Aracena, es un representante típico de la nueva burguesía ennoblecida, terrateniente, tradicionalista, y eje de un sistema caciquil eficaz en el control político de la comarca mediante el recurso a las relaciones de clientelismo.

Sin embargo este hecho histórico, relevante en sí mismo por lo que fue la materialización de la apropiación del capital simbólica de ermita e imagen por la oligarquía que detenta el poder, lo es también por lo que supondría su proyección en el futuro. En su momento representó un encuentro cíclico anual de los representantes de las oligarquías locales en el santuario de la Peña. No existen hermandades formalizadas y la presencia de los individuos de cada "pueblo" lo harán en base a sus vinculaciones de clase dominante. Incluso se describe como "reuniones de familia" dada las relaciones de parentesco existentes con frecuencia entre los miembros de las diferenters oligarquías locales, consecuencia de la fuerte endogamia de grupo que los caracterizó. Los demás habitantes de los "pueblos" representados asisten como observadores, o bien lo harán de forma marginal, supeditados a las normas impuestas por las elites organizadores.

La guerra civil, la desaparición de los principales patrones-caciques a la par que el sistema de clientelismo que impusieran, al mismo tiempo que la propia estructura de poder que primó el dominio de la tierra como factor económico y de prestigio, supone también la decadencia del modelo organizativo y de control sobre la imagen/santuario. Situación que se acelera y hace irreversible desde los años 50 y 60 , con la crisis generalizada del sistema tradicional de producción agropecuaria, por su escasa rentabilidad y la consiguiente secuela de emigración y abandono de los campos.

No obstante, no desaparece el esquema embrionario del ritual supracomunal creado en torno a las organizaciones socioceremoniales que conforman las "hermandades" constituidas por los romeros de cada "pueblo". Sólo que ahora son las "hermandades" en sí (reconocidas o no eclesiásticamente) las que cobran especial relevancia. Su revitalización se produce a partir de los años setenta, a la par que culminan los cambios estructurales que han afectado a las diferentes poblaciones serranas. Las viejas oligarquías han desaparecido. Son sustituidos por miembros 
de nuevos sectores sociales, con rentas provenientes de diversos sectores productivos, que acaparan las fuentes de poder político-administrativos locales, a la vez que las instituciones socioceremoniales buscando refrendar de este modo la nueva posición de prestigio y poder social alcanzada.

Al mismo tiempo, la quiebra de los viejos modelos de sociedad fuertemente dicotomizados en torno a la tiепа como base productiva casi exclusiva, ha dado paso, siempre en el contexto relativo de la precariedad económica que caracteriza a las poblaciones de esta comarca onubense, a una mayor flexibilización y dinamismo en las redes sociales y de poder, implicando a un mayor número de personas, hasta generar, observable en el caso de las hermandades, una idea de igualitarismo y ruptura de las viejas normas de adscripción y participación que refleja, simbólicamente, la idea de participación/representación de la colectividad glogal.

Idea de igualitarismo que debemos seguir cuestionando. Al igual que se han revitalizado en un nivel intralocal las antiguas instituciones sotioceremoniales como iustrumentos que refrenden la posición socioeconómica lograda por nuevos sectores sociales, procurarán proyectarla también en un nivel intercomunal si existe la posibilidad de manifestarla; lo que ocurre con el tiempo de encuentro contrastivo que representa la romería supracomunal. Sólo que, como acabamos de decir, en la medida en que la mayor amplitud ( $y$ ambigüedad) de las relaciones sociales ha propiciado la percepción identitaria como "pueblo" a través de la participación de los rituales en la romería supracomunal, el mismo tiempo contrastivo servirá para poner de manifiesto la desigual posición que los colectivos de referencia (poblaciones) tienen en las relaciones de poder intercomunales.

El resultado es un juego complejo de alianzas e intereses que trasunta en términos simbólicos, en la pugna por el control de la imagen, las tensiones existentes entre las poblaciones que comparten el territorio. Para Alájar, la circunstancia de ser la hermandad matriz y la población propietaria de imagen y santuario hace que la presencia de otros pueblos/hermandades filiales reafirmen su preeminencia simbólica que no se corresponde con la posición ocupada en la escala de poder intercomunal: ampliamente rebasada en su potencialidad económica y demográfica por otras poblaciones que acuden a la ermita, como Aracena o Galaroza.

En contraposición, Aracena, con la argumentación "histórica" aún recurrente de que Alájar (y por lo tanto la Peña) fue en cl pasado una localidad dependiente, constituiría una "amenaza" a su propia capacidad organizativa y de manifestación comunal, al contar con la potencialidad referida (económica y demográfica), puesta de manifiesto en su presencia ostentosa en la romería de septiembre. 
Alájar deberá recurrir, incluso apoyándose económicamente, a la presencia de otras hermandades (Linares, Galaroza, Fuenteheridos) situadas en una posición dependiente (por su escasa representatividad en las poblaciones de origen, apoyos económicos de la hermandad matriz, etc.), que le servirán para contrarrestar la prepotencia de Aracena.

De este modo, una ocasión aparentemente restringida a una manifestación religiosa y con un ritual preciso, sirve para expreasr la tensión latente en la subcomarca histórica de la que hablamos, provocada por las condiciones ventajosas que acapara Aracena (justificada por las razones referidas), y que la hacen oupar una posición privilegiada, no aceptada por el resto de las poblaciones, en cuanto a los beneficios que obtiene de la concentración del control administrativo y de servicios del conjunto del espacio común compartido. Por ello, la existencia de las demás hermandades filiales (Galaroza, Linares, Fuenteheridos) no sería cuantificable en términos de su peso específico real en el proceso organizativo y en el desarrollo de los actos ceremoniales, pero si en cuanto "poblaciones" que contrarrestan la presencia y potencia impositivo de Aracena.

Las hermandades que acuden a la ermita lo harán con una significación dentro del sistema organizativo devocional de cada población muy dispar. Sólo Aracena, además de Alájar, ha hecho de la romería de la Reina de los Angeles una expresión comunal de destacada pujanza: carente de otros rituales análogos (romerías) que le permitan exteriorizar de forma visible, en un espacio abierto, tanto su sentido de integración comunal como su capacidad de convocatoria y diferenciación respecto a las localidades vecinas, ha recurrido a esta ocasión propiciatoria para competir ventajosamente con las demás poblaciones. La ostentación formal de la que harán gala (cifra de carretas muy superior a la de las demás poblaciones, engalanado de las mismas, número de caballerías, etc.) es considerada intencional por los asistentes de los otros pueblos, para que "Aracena" destaque com la población "más rica" de la comarca.

Si bien, esta desigualdad en sus significados no supone que cada población deje de procurar testimoniar su propia identidad. La confluencia referida en un mismo lugar y tiempo no significa indiferenciación. Por el contrario, cada hermandad, recreando un sentimiento identificatorio en último término referido a la propia localidad de origen, ha generado su propio tiempo ritual, singularizado la decoración de sus carretas, prefijado un camino propio con los correspondientes sitios de parada, horarios de salida, etc., para culminar en la ocupación de espacios específicos asignados a cada "pueblo" en la explanada de la peña, acotados mediante postes y cordeles. 


\section{BIBLIOGRAFÍA}

AGUDO TORRICO, J. (1990) "Mayordomías-hermandades. Procesos de transformación en la formalización y control de las asociaciones religiosas en la Sierra Onubense". V Congreso de Antropología. Granada, sin publicar.

- (1991). Las hermandades de la Virgen de Guía en Los Pedroches. Caja Provincial de Ahorros de Córdoba, Córdoba.

AGUDO TORRICO, J. y ESCALERA REYES, j. (1992). "Santuarios, devociones, fiestas e identidad: simbolismo y territorialidad en la Sierra de Aracena". J.A. Domínguez Márquez y J. Pérez Embid. Huelva en su historia, n.․ 4. Monte y Caja de Ahorros de Huelva y Sevilla. Huelva, págs. 465-480.

BOURDIEU, P. (1971). "Genese et structure de champ religieux". Revue française de Sociologie XII.

(1991) 1980. El sentido práctico. Ed. Taurus, Madrid.

CARO BAROJA, J. (1968). "Sobre los conceptos de región y comarca". Estudios sobre la vida tradicional española. E. Península. Barcelona, págs. 307-318.

(1974) Ritos y mitos equívocos. Istmo. Madrid.

CHRISTIAN, W. (1976). "De los santos a María: Panorama de las devociones a santuarios españoles desde el principio de la Edad Media hasta nuestros días".

C. Lison (ed.). Temas de Antropología Española. Akal. Madrid, págs. 49-105.

(1978) Religiosidad popular. Estudio antropológico de un valle español. Tecnos. Madrid.

(1991). Religiosidad local en la España de Felipe II. Nerea. Madrid.

DELPECH, F. (1990). "Simbolique territoriale et systeme sacrificial dans un ancien ritual de 'terminatio' andalou: notes pour une anthropologie des confins". La fiesta de ceremonia, el rito. Casa de Velázquez y Un. de Granada. Granada, págs. 147-164.

DÍEZ TABOADA, J.M. (1989). "La significación de los santuarios". Alvarez Santaló, C. Buxó, M.J. y Rodríguez Becerra, S. (coords.). La religiosidad popular. III. Hermandades, romerías y santuarios. Anthropos. Barcelona, págs. 268-281.

ESCALERA REYES, J. (1990). "Estructuras sociales, sistemas de relaciones de poder y manifestaciones festivo-ceremoniales: el caso de la Peña de Arias Montano en la Sierra de Aracena (Huelva)". V Congreso de Antropología. Granada, sin publicar.

(1991). "Simbolismo y territorio en la Sierra de Aracena". Anuario Etnológico de Andalucía, 1988-90. Junta de Andalucía. Sevilla, págs. 209220. 
LEACH, E. (1985) (1976). Cultura y comunicación. La lógica de la conexión de los simbolos. S. XXI. Madrid.

LISÓN TOLOSANA, C. (1980). Invitación a la Antropología cultural de España. Madrid.

MALDONADO, L. (1982). "Los santuarios en la religiosidad popular". Santuarios del país vasco y religiosidad popular. Facultad de Teología. Vitoria, págs. 7-21.

MORENO ALONSO, M. (1979). La vida rural en la Sierra de Huelva. Alájar. Instituto de estudios onubenses. Sevilla.

MORENO NAVARRO, I. (1974). Las hermandades andaluzas. Una aproximación desde la Antropología. Universidad de Sevilla, Sevilla.

(1990a). "Rituales colectivos de religiosidad popular y reproducción de identidades en Andalucía". Identidades colectivas. etnicidad y sociabilidad en la Península Ibérica. Cucó, J. y Pujadas, Joan J. (coords.) Generalitat valenciana. Valencia.

(1990b). "Niveles de significación de los iconos religiosos y rituales de reproducción de identidad en Andalucía”, Las fiestas, la ceremonia, el rito. Casa de Velázquez y Universidad de Granada, Granada, págs. 91-104.

(1991). "Identidades y rituales" J. Prat, U. Martínez, J. Contreras, I. Moreno (eds.). Antropología de los pueblos de España. Taurus, Madrid, págs. 601636.

PRAT I CAROS, J. (1989). "Los santuarios marianos en Cataluña: una aproximación desde la etnografía" Alvarez Santaló, C. Buxó, M.J. y Rodríguez Becerra, S. (coords.) La religiosidad popular. III. Hermandades, romerías y santuarios. Anthropos. Barcelona.

TURNER, V. (1980) (1967). La selva de los símbolos. S. XXI, madrid. (1988) (1969). El proceso ritual. Ed. Taurus, Madrid.

VELASCO, H. (1991). "Signos y sentido de la identidad de los pueblos castellanos. El concepto de pueblo y la identidad",. J. Prat, U. Martínez, J. Contreras, I. Moreno (eds.). Antropología de los pueblos de España. Taurus, Madrid, págs. 719-728. 